\title{
Oil and Gas Transportation: Is Contract a Viable ALTERNATIVE TO TRADITIONAL REGULATION?
}

\author{
J. DAVID BRETT* AND NADINE E. BERGE**
}

The article reviews both the provincial and federal legislative frameworks governing access to oil and gas pipelines, with emphasis on dispute resolution options in the case of access and toll disputes. These codified obligations are compared with the traditional common law common carrier obligations. and it is demonstrated that the latter still play an important role in roday's regulaton' emvironment.

Key regulatory decisions of both the National Energy Board and the Alberta Energy and Uilities Board are examined to demonstrate both the approaches of these bodies in encouraging sethlement of oulstanding isstues. and their atritudes woward yielding regulatory jurisdiction when partics' affairs have been arranged by contract. It is demonstrated that these regulaton' bodies still maintain jurisdiction over some aspects of oil and gas transportation even where parties have agreed to privalely dranin oil or gas pipeline contracts and will not hesitate to interfere given the right public policy concerns.
Cet arficte examine les lois provinciales ef federales regissam / accies aux oliuducs ef ant gazodics. fout en accordam une atfention speciale atex options de resolution de conflits relarifs à l'uccès el aux droits. Ces obligations codifiecs som comparées anx obligations traditionnelles de common lanv à l'ègard du transporteur commun. et on démontre que la common law jowe encore un róle important dans le monde réglemenlaire d'aujourd hui.

Des décisions cles réglementaires de 1 Office national de I'energie et du Alberta Energl' and Utilitics Board son examinees dans le bu de montre les demarches que ces organismes fom pour encouruger le riglemen de questions en suspens et les anindes qu iis adople'nt à 'égard de la cession de la juridiction réglementaire' larsque les parties se somt emendues par comtrat. On demontre que ces organismes de réglementation gardent leur compétence en matière de certains aspects du transport pétrolier et gazier mème si les parties, en privé, ont conclu des contrats et qu'its $n$ hésiteront pas à s'ingerer dans le cas de bomes politiques d'interét public.

\section{TABLE OF CONTENTS}

I. INTRODUCTION ........................... 94

II. Common Carrier Obligations $\ldots \ldots \ldots \ldots \ldots \ldots \ldots \ldots \ldots \ldots$

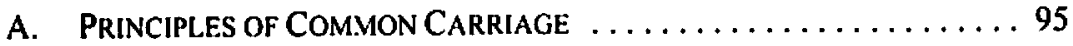

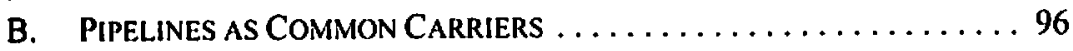

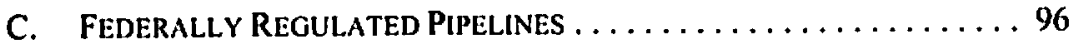

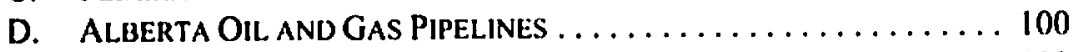

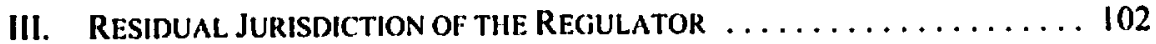

A. Settlements ....................... 102

B. Contractual Carriage .................. 104

IV. Common Carrier Obligations Revisited $\ldots \ldots \ldots \ldots \ldots \ldots \ldots$

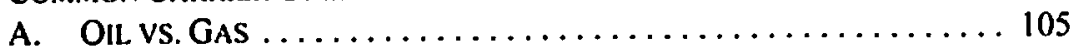

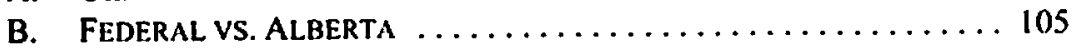

C. Myths Exploded(ERoded?) $\ldots \ldots \ldots \ldots \ldots \ldots \ldots \ldots \ldots \ldots \ldots$

D. Producers as Pipeline Owners/Developers . . . . . . . 108

- Partner at Gowling Lafleur Henderson LLP, Calgary, practising in the areas of utility and energy regulation, infrastructure development, and environmental and aboriginal law.

- At the time of writing this anticle, Senior Associate at Gowling Lafleur Henderson LLP, Calgary, with a practice in regulatory and environmental law, as well as commercial litigation. Ms. Berge is currently legal counsel with TransCanada PipeLines Lid., Calgary, in the regulatory area. 
E. OIL Piplilines as Common CARrJers $\ldots \ldots \ldots \ldots \ldots \ldots \ldots$

V. Contract Carriage Arrangements $\ldots \ldots \ldots \ldots \ldots \ldots \ldots \ldots$

A. The OIL Sands Case $\ldots \ldots \ldots \ldots \ldots \ldots \ldots \ldots \ldots \ldots \ldots \ldots$

B. THE MAJOR ISSUES $\ldots \ldots \ldots \ldots \ldots \ldots \ldots \ldots \ldots \ldots \ldots \ldots \ldots \ldots$

VI. CONCLUSION .................................. 113

\section{INTRODUCTION}

At the conceptual stage, this article was intended to compare and contrast traditional regulation of oil and gas pipelines on the one hand, with "regulation" by contract among shippers and a pipeline on the other, focusing particularly on recourse available in the event of disputes. The draft thesis was that parties' needs could be served by the latter without the expense, distractions, and ill will occasioned periodically by the former.

The issucs surrounding the siting of facilities and the traditional approval processes were not contemplated. It was assumed that government regulation would apply to these issues. Rather, "regulation" in this context was intended to relate to economic regulation, by which is meant the charges (tolls, in pipeline parlance) for the service, as well as the fundamental terms and conditions of service (including access) that impact a shipper's economic wellbeing.

Regulation by contract is an oxymoron. To assist in overcoming this intellectual and etymological curiosity, regulation is here interpreted as a structural framework that provides rules for putting a deal together and resolving disputes. This model is perhaps more easily envisioned with a "regulator" present, and conforms comfortably to our notions of the public interest and the protection and enhancement thereof. However, the "constitutional" nature of the concept - a framework to do business and resolve differences - readily adapts to, and indeed can be established by, a contractual setting.

Returning then to the original concept, as research and thought progressed it became apparent that:

(a) proving or disproving the thesis was difficult, inasmuch as access to private arrangements - that is, pipeline transportation agreements - and the results of arbitrations or other dispute resolution mechanisms, was problematic at least in a public way; and

(b) the thesis may well have been moot, because regulators continue to hold jurisdiction over contracting parties and their arrangements (or potential newcomers to those arrangements), although such jurisdiction is often not exercised or even threatened, or the regulator defers to the positions of the parties.

The second point is important for two reasons. First, as will be demonstrated below, recourse may always be had to a regulator. Second, that very fact may operate to an unknown degree as a form of moral suasion informing how shippers and pipelines approach creation of their "constitution" in the first place. 
The topic, in its original context, remains of considerable interest. Hundreds of gas lines operate within Alberta moving gas from field to pipeline. They are producer-owned, and many carry third party gas. While in some cases access was ordered by a regulator, most of these arrangements (including charges) were entered into through negotiations between the parties. The same is true for gas processing plants.

Many large new pipeline projects are proposed in both the oil and gas sectors, including some dealing with incremental oil sands product. Whether advanced in a conventional way through a regulator, through boardroom negotiations, or both, the issues are the same.

To this point, output from the oil sands in large part moves by pipeline on the first leg of its journey pursuant to arrangements entered into between producers and pipelines. These arrangements, which will be discussed below, take the form of very detailed contracts which look much like pipeline tariffs, augmented to create the tolling and dispute resolution components of the "constitution" referred to above. All operate outside regulatory purview, although, as will be demonstrated below, recourse to a regulator is available.

Further, the issue of access or priority access is becoming increasingly important for existing pipelines (Chevron application to the National Energy Board for priority on the Terasen (TransMountain) system), expansion to existing lines (Terasen (TransMountain)), and greenfields projects (e.g. Mackenzie Gas Project). Indeed, satisfactory resolution of access, the terms on which it is granted, and related provisions, may be determinative of whether a project proceeds.

In this environment, therefore, a study of the legislative framework governing access to pipelines, dispute resolution (for access, tolls or other disputes), and the major issues (relating to access, cost responsibility, and other critical factors) to be resolved by parties, whether through negotiation, or submissions to and decisions by regulators, or both, is timely. This article will address all three.

This article begins by reviewing the common carrier concepts under both federal and Alberta law for both oil and gas pipelines, including a discussion of key regulatory decisions. It brielly summarizes both National Energy Board (NEB) and Alberta Energy and Utilities Board (AEUB) approaches to setllement of outstanding issues by negotiation, and deals with the residual jurisdiction of regulators even where parties have arranged their affairs by contract.

The last section of this article will touch on the significant business and legal issues addressed in certain oil sands pipeline agreements that must be resolved for all of the major pipelines currently being proposed or planned.

\section{iI. Common Carkier Obligations}

\section{A. Principles of Common Carriage}

Common carrier obligations arose originally at common law. Black's Law Dictionary defines the obligation as: 
A commercial enterprise that holds itself out to the public as offering to transport freight or passengers for a fee. A common carrier is gencrally required by law to transport freight or passengers or freight, without refusal, if the approved fare or charge is paid.'

At common law, a common carrier's liability is that of an insurer, and it must indemnify the shipper for any damage or loss of the goods as long as they remain in its hands. ${ }^{2}$ In the event that there is insufficient capacity to carry the desired amounts, it is common for the amounts carried to be adjusted pro rafa. This latter structure is frequently observed in common carrier pipelines, although as will be seen the pro rata allocation feature has been eroded.

\section{B. Pipelines as Common Carriers}

The principles of common carriage have been applied to pipelines through statute at both the federal and provincial levels. For parties seeking transportation of oil and gas, a declaration of common carrier (or enforcement of that statutory obligation) has frequently been the method of choice for access. The following section discusses the legislation of Canada and Alberta and the decisions of the relevant regulatory bodies with respect to pipeline common carrier obligations.

\section{Federally Regulated Pipelines}

The provision relating to common carriage obligations at the federal level is $\mathrm{s} .71$ of the National Energv Board $A c t,{ }^{3}$ which reads as follows:

\section{Duty of pipeline company}

71. (1) Subject to such exemptions, conditions or regulations as the Board may prescribe, a company operating a pipeline for the transmission of oil shall, according to its powers, without delay and with due care and diligence, receive, transport and deliver all oil offered for transmission by means of its pipeline.

Orders for transmission of commodities

(2) The Board may, by order, on such terms and conditions as it may specily in the order, require the following companies to reccive, transport and deliver, according to their powers, a commodity oflered for Iransmission by means of a pipeline:

(a) a company operating a pipeline for the transmission of gas; and

(b) a company that has been issued a certificate under section 52 authorizing the transmission of a commodity other than oil.

Black's Law Dictionany, 8th ed., s.v. "carrier."

Tri-City Drilling Co. v. Velie(1960), 22 D.L.R. (2d) 341 (Alta.S.C. (T.D.)), aff'd(1960), 25 D.L.R. (2d)

773 (Alta. S.C. (A.D.)).

R.S.C. 1985. c. N-7, s. 71 [NEB $A C t]$. 


\section{Extension of facilities}

(3) The Board may, if it considers it necessary or desirable 10 do so in the public interest, require a company operating a pipeline for the transmission of hydrocarbons, or for the transmission of any other commodity authorized by a certificate issued under section 52 , to provide adequate and suitable facilitics for

(a) the receiving. transmission and delivering of the hydrocartons or other commodity offered for transmission by means of its pipeline.

(b) the storage of the hydrocarbons or other commodity, and

(c) the junction of its pipeline with other facilities for the transmission of the hydrocarbons or other commodily.

if the Board finds that no undue hurden will be placed on the company by requiring the company to do so.

\section{OIL PIPELINES}

Most common carrier decisions of the NEB have been in relation to oil pipelines. Section $71(1)$ provides that every oil pipeline operator has the obligation to "receive, transport and deliver all oil offered for transmission" through its pipeline. Section 67 of the NEB ACr" prohibits "unjust discrimination in tolls, service or facilities against any person or locality." Sections 67 and 71 have been interpreted together to mean that an oil pipeline must offer service under the same terms and conditions to any party wishing to ship oil on that pipeline.' In a 1984 decision in which Gulf Canada Limited applied to ship refined product with TransMountain Pipeline (now Terasen), the NEB held that TransMountain was under a prima facie duty to ship all oil tendered to it unless it could convince the NEB that for some reason, such as safety or capacity, it could not.

It should be noted that the opening words to $5.71(1)$ are "[s]ubject to such exemptions, conditions or regulations as the Board may prescribe."

The NEB has modified the duty described above by making it into a more relative obligation. In a 1996 application ${ }^{7}$ by PanCanadian Petroleum Limited for access to Interprovincial Pipe Line Inc. (IPL) in order to ship natural gas liquids (NGLs), the NEB stated that the statutory common carrier obligation was tempered by a test of reasonableness.

Ibid.

- NEB. Federated PipeLines (Northern LAd). Facilities Application, Reasons for Decision OH-3-96. (April 1997) at 13 [Federated Pipel.ines].

- NEB. In the Matter of an dpplication Pursuant to Section 59 of the National Energy Bourd Act of Giulf Canada Limited, Reasons for Decision RH-4-84 (December 1984) at 1.

7 NEB, PanCanadian Petrolenm limited, Request for Service. Reasons for Decision MH1-4-96 (February 1997) at 11 .

* Citing the Supreme Court or Canada in A.L. Patchett d Sons LAd. v. Pacjfic Great Eastern Railway Co. [1959] S.C.R. 271. 
It went on to say that the obligation was limited by two factors: first, the company was only obligated to act in accordance with the powers devolved upon the company by statute law and by its corporate constitution; and second, the obligations of the oil pipeline owner are limited by published tariffs. The NEB noted: "However, since the obligations of an oil pipeline company to receive, transport and deliver oil are statutory obligations, no provision in the company's tariffs may detract from those obligations which are imposed by the $N E B$ Act."

The NEB linished by noting that

\begin{abstract}
the Board's inclination is to look first to the pipeline and the energy industry to create market-responsive solutions. In this particular instance, the Board has made known its concems about the lack of open acess services in respect of the transportution by IPL of NGL. It believes that the facts disclosed in this proceeding call for a broader solution to the impediments faced by those who wish to ship NGL. as shippers of record, than is achieved by the granting of 'PanCanadian's application. The Board therefore encourages IPL and the NGL industry to conperate in devising a long term solution which will provide the neeessary senvices of receipl, transportation and delivery on an economic basis of all NCiL ollered for transportation by all potential NGL shippers on IPL.."
\end{abstract}

The NEB has also held that contracts that provide secure access for shippers supporting the pipeline through long-term shipping contracts do not violate the prohibition on unjust discrimination in s. 67." However, at the same time, it emphasized that its statutory powers are not constrained by contracts between individual parties and that it would act to protect the public interest in future proceedings. The NEB made a similar finding in an application by Novagas Clearinghouse Pipelines Ltd. to build an NGL line between Taylor, B.C. and Boundary Lake. Alberta.'2

In Interprovincial Pipe Line Company, ${ }^{13}$ the NEB granted shippers with firm long-term contracts unapportioned access to the line on the basis that there were sufficient obligations imposed upon them under the Facilities Support Agreement. The NEB held that "so long as a pipeline gives all parties the same opportunity, at the same time, to participate in a project or avail themselves of a particular service, then that pipeline's common carrier [status] is maintained."14 This theme was picked up in Express Pipelines Lid., ${ }^{15}$ and in Trans-Northern Pipelines $/ n c{ }^{16}{ }^{1 t}$ was made clear in Trans-Northern that granting priority access to certain shippers who had signed long-term contracts pursuant to the offering of contract capacity referred to as an open season did not require an exemption from the s. 7/(1) common carrier obligations.

Supra note 7 at 12.

lbid. at 14.

Federated Pipe Lines, supra note 5 at 14.

NEB, Novagas Cleuringhouse Pipelines Lda., Reasons for Decision OH-2-96 (May 1997) at 13-14. NEB, Interporovincial Pipe Linc Compomy: a division of Imerhome Energl Inc. Reasons for Decision GHW-5-90 and RH-3-90 (Fsbruary 199i).

lhid. at 31 .

NEB. Express Pipelines L.W.. Facilities and Toll Methodology, Reasons for Decision OH-1-95 (June 1996) [Express Pipelines].

NEB, Trans-Nomhern Pijelines Inc. Facilities, Reasons for Decision OH-1-2003 (July 2003) [TransNorthern]. 
In Interprovincial Pipe Line Company (Line 9 Reversal), ${ }^{17}$ the NEB reiterated that the requirements of s. 71 are not absolute and that it can grant exemptions from its requirements if necessary. It further stated that it was of the view that many different arrangements (such as a properly conducted open season) could be made to ensure that an oil pipeline is complying with s. 71 of the NEB ACt. ${ }^{\text {ts }}$ It examined the opportunity that IPL had provided to other shippers to participate in the Line 9 Reversal, and determined that there had been considerable uncertainty associated with it. In addition, Line 9 was the only direct connection to bring offshore crude oil to the Ontario market. For these reasons, the NEB ordered that 80 percent of the capacity would be reserved for firm shippers, and 20 pereent for other shippers on a common carrier basis.

The NEB has also agreed to allow the termination of a common carrier obligation in certain instances, such as where the pipeline was a lateral and where the NEB concluded that it was not economical to operate and there would be no appreciable impact on the broader public interest. ${ }^{14}$

\section{GAS PIPELINES}

With respect to gas pipelines, s. 7I(2) of the $N E B A C r^{20}$ provides that the NEB may require a company operating a pipeline for the transmission of gas "to receive, transport and deliver" gas offered by a person for transmission by means of a pipeline. In effect, absent an order of the NEB, a gas pipeline is not a common carrier. However, applications to compel service with respect to gas have been more unusual than those relating to oil.

In 1996, the NEB considered a request to issue an order to compel the transport of gas for Renaissance Energy in respect of TransCanada PipeLines Lid.'s(TCPL) 1997/1998 Facilities Application. Renaissance Energy requested service from Empress. Alberta to Emerson, Manitoba in order to serve sugar beet customers for part of the year and to sell into short term export markets for the remainder of the year. TCPL had refused to include the request on the basis that it was not satisfied that Renaissance Energy had demonstrated long-term downstream take-away arrangements and markets, using the usual tests. The NEB indicated that it was willing to intervene on the basis that the public interest would be served by a different interpretation of TCPL's tariff, although it stressed that this was an exceptional case and each application would have to be considered on its own merits."

More recently, BC Gas proposed to build a new pipeline that would compete directly with the Westcoast Pipeline System (Westcoast). It applied for transportation on Westcoast much further downstream than its previous input and intended to contract for lirm service at this downstream point. The NEB made the decision to grant access on the basis that it was in the

17 NEB, Interprovincial Pipe Linc Inc. Facilitics and Toll . Wethodologi. Rcasuns for Decision OH-2-97 (December 1997) [Line 9 Reversal].

18 $\quad$ bid. at 53 .

10 NEB, Trans-Northern Pijulines Inc.. Suspension of Service. Reasons for Decision MH-3-2000 (November 2000) at 13.

so Supra note 3.

21 NEB, TransCanada Pipelines Lid., Facilities Application, Reasons for Decision Git-3-96 (November 1996) at $42-47$. 
public interest to allow greater choice to the markets served by Westcoast and that other concerns could be dealt with through the tolling structure and by the British Columbia Utilities Commission (BCUC). ${ }^{22}$

\section{Alberta Oil and Gas Pipelines}

Sections 48 and 49 of the Alberta Oil and Gas Conservation Act ${ }^{23}$ reads as follows:

Common carrier

48 (1) On application the Board, with the approval of the Lieutenant Governor in Council, may from time to time declare each proprietor of a pipeline in any designated part of Alberta or the proprietor of any designated pipeline to be a common carrier as and from a date fixed by the order for that purpose, and on the making of the approved declaration the proprietor is a common carricr of oil, gas or synthetic crude oil or any 2 or all of them in accordance with the declaration.

(2) No proprietor of a pipeline who is a common carrier shall directly or indirectly make or cause to be made or suffer or allow to be made any discrimination of any kind as between any of the persons for whom any oil, gas or synthetic crude oil is gathered, transported, handled or delivered by means of the pipeline.

(3) No common carrier shall discriminate in favour of the common carrier's own oil, gas or synthetic crude oil or oil, gas or synthetic crude oil in which the common carrier is directly or indirectly interested either in whole or in part.

(4) On application the Board, in order to give effect to a declaration under subsection (1), may direct

(a) the point at which the common carrier shall take delivery of any production to be gathered, transported, handled or delivered by means of the pipeline, or

(b) the proportion of production to be taken by the common carrier from cach producer or owner offering production to be gathered, transported, handled or delivered by means of the pipeline.

Relief to common carrier

49 The Board, by order, may relieve any common carrier from the duty of carrying any oil, gas or synthetic crude oil of inferior or different quality or composition or from any other duties that in its opinion are unreasonable.

Thus, the AEUB has the express power to make common carrier orders. Such an order promotes the objective identified by s. 4(d) of the OGCA of giving each owner the opportunity of obtaining its share of the production of oil or gas from any pool. Section 48 of the $O G C A$ provides that the AEUB may, with Cabinet approval, declare a pipeline proprietor in the province to be a common carrier of oil or gas. As a common carrier, the 
pipeline proprietor will be prohibited from discriminating between sources of supply and/or in favour of oil, gas, or synthetic crude oil in which they have an interest. ${ }^{24}$ Section 49 provides that the AEUB may relieve a common carrier from the duty of carrying a product of inferior or different quality or from other duties it finds to be unreasonable.

Section 56 of the $O G C A$ allows an applicant to request that the common carrier order be made effective retroactively to the date of the application. The AEUB has discretion on this point and will consider the applications on a case-by-case basis. Sections $48(4)$ (a) and (b) also permit the applicant to request that the AEUB direct the point at which the common carrier shall take delivery of the production, and the proportion of production to be taken by the common carrier from each producer or owner offering production to be gathered, transported, handled or delivered by means of a pipeline. Disputes between common carriers and suppliers can be referred to the Public Utilities Board, now the AEUB."s

The AEUB has recently issued Directive 065: Resources Applications for Conventional Oil and Gas Reservoirs. ${ }^{26}$ It replaces the previous Guide 65 and explains how the AEUB will deal with common carrier applications. It notes that the applicant may choose to request that the AEUB set tariffs at the same time as its common carricr obligation, but that the selting of tariffs may be deferred to permit further negotiations among the parties.

The following criteria are considered for approval of the common carrier application in Alberta:

- producible reserves are available for transportation through an existing pipeline.

- There is a reasonable expectation of a market for the subslanec that is proposed to be transported by the common carricr opcration.

- the applicant could not make reasonable arrangements to use the existing pipeline.

- the proposed common carrier operation is either the only cconomically feasible way or the most practical way to transport the substance in question or is clearly superior environmentally, and

- where application is being made under Sections $48(4)($ a) and/or (48(4)(b) of the [OGCA] for the designation of a delivery point and/or the proportion of production to be delivered to the pipeline, that the applicant could not make reasonable arrangements on these matters. ${ }^{27}$

These criteria have been developed over time in a series of AEUB decisions. Directive 065 states that parties are expected to make "substantial efforts" to negotiate a common carrier arrangement and file an application with the AEUB only as a last resort. In Signalta

3t AEUB, Dircctive 065: Resources Applications for Comentional Oil and Gas Rescrwoirs (30 November 2004) (formerly Guide 65). online: AEUB <www.eub.gov.ab.ca/bbs/documents/directives/Directive 065.pdl> [Directive 065].

$27 \quad$ lbid., s. 1.3 .4 at 34 . 
Resources $L t d .{ }^{2 \times}$ the AEUB stated that "normal commercial arrangements are best resolved through fair and honest negotiations between the parties," and that "such issues should only be resolved by regulatory order as a last resort." pipelines involved are frequently in the nature of gathering systems and, therefore, issues of unitization and drainage may be involved. ${ }^{30}$ The AEUB may also look to the general objectives of the $O G C A$. such as the desirability of avoiding unnecessary duplication of facilities. ${ }^{31}$

The AEUB has also considered the issue of whether pipeline rates, tolls, and charges that are set out in legally binding contracts could be subject to the jurisdiction of the AEUB. In Decision E94047, ${ }^{32}$ the AEUB indicated that it preferred to base its decision on the fact that there were no contracts in existence between the parties. However, it concluded that it did have jurisdiction to fix just and reasonable rates, tolls, and charges even if the effect would be to override existing contracts and even if no application were made expressly to bring the pipeline under the provisions of the Public Uisitities Board Act. ${ }^{3.3}$

Both Alberta and federal regulators will give a great deal of deference to the ability of parties to resolve their differences informally, and more significantly, to address access to pipelines by contract, even where that limits the "public" access that common carriers are supposed to provide. In particular, the NEB has shown a definite inclination to allow parties that have provided significant financial backstopping for pipelines to have rights above and beyond those to which they would normally be entitled under a common carrier regime. However, this inclination is balanced with a desire to maintain some regulatory oversight, as discussed in the next section.

\section{RESidUAl, JURISDiCTION OF THE REgULATOR}

\section{A. SetTlenents}

\section{NATIONAL. ENERgY BOARD}

Negotiated settlements are dealt with in the NEB's Revised Guidelines for Negotiated Setlements of Traffic. Tolls and Tariff.s. ${ }^{34}$ The Guidelines state that the NEB views the process as an opportunity for interested parties to resolve issues without resorting to a hearing process. The NEB sets out its expectations as to how the process will unfold. It also emphasizes the continuing jurisdiction of the NEB - for example, that the NEB's discretion to take into account any public interest considerations is unfettered, and that it will not accept

Energy Resourees Conservation Board. Common Carrier. Sugden Grand Rapids $H$ and Colony Undefined Pools, Reasons for Decision D92-1 (16 April 1992) [Signalta Resources Lid.].

Ibid. at 8.

See e.g. AFUl3, Cubre Explorotion I.de., Gas Injection/Rateable Tuke Common Carricr/Common Processor Kiskwed d Cardism a Peol. Decision D-96-6 (26 September 1996).

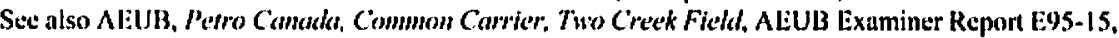
(12 December 1995); the Examiner's recommendations were endorsed by the AEUB in AEU13 decision D95-15 (21 December 1995).

Re: Peace Pipe line L.td. (3 August 1994) [Peace Pipe Line].

R.S.A. 2000, c. P.45 [PUB ACt].

(12 June 20(12) [Guidelines]. 
settlements that contain provisions that are illegal or contrary to the $N E B A C t$, or that are otherwise contrary to the public interest (as, presumably, defined by the NEB).

The Guidelines also require that the settlement process produce adequate information on the public record for the NEB to understand the basis for the agreement, to assess its reasonableness, and to be able to determine that the resulting tolls are just and reasonable and not unjustly discriminatory. Where the settlement is not opposed by any party, the NEB is normally able to conclude that the resultant tolls are just and reasonable and a public hearing is not required.

Where all parties do not agree to the settlement, the pipeline company can nonetheless file an application for approval. The company must provide a submission as to why the settlement should be accepted by the NEB. The NEB also receives submissions from parties that do not support the settlement. The NEB then makes the determination to approve the settlement, refer the matter for hearing, or approve the settlement on an interim basis and hold a hearing to deal with the issues raised by the dissenting parties.

In all of the scenarios outlined above, the NEB maintains significant control over the process, and ultimately makes the decision whether to approve the settlement. The power of the parties to the settlement is limited, particularly where a unanimous agreement cannot be reached.

\section{ALBERTA ENERGY AND UTII.ITIES BOARD}

The AEUB has issued Directive 0/8: Negotiased Setlement Rules. ${ }^{36}$ The AFUB states that it views the negotiated settlement process as a way to achieve greater regulatory efficiency and effectiveness, as well as to encourage greater stakeholder participation. It specifies that the settlement process should take place on a confidential basis. No discussions from the settlement negotiations may be put before the AEUB in a hearing context without consent of all the parties to the negotiation.

Parties wishing to initiate a settlement process must notify the $A$ EUB and provide an outline of the pertinent issues to be resolved. AEUB approval is required for the negotiation to proceed and the AEUB may direct the parties to include or exclude certain issues. $A$ decision by a party not to participate in the settlement negotiations does not abrogate the ability of that party to intervene on an application filed with the AEUB.

Thus, the AEUB maintains a significant presence in the process and clearly does not relinquish control over its process in favour of settlement negotiations. Furthermore, it maintains the jurisdiction to approve the settlement and will consider whether it is in the public interest, is reasonable and fair to all parties, is rationally substantiated, and is supported by a complete and adequate application. Even where a settlement is unanimous or 
unopposed, the AEUB will still consider a number of criteria to ensure that the settlement is fair and to assess whether it results in rates, terms, and conditions that are just and reasonable. Having said that, unanimous settlements will generally be approved unless they are determined to be patently against the public interest or contrary to law.

The AEUB's final jurisdiction over negotiated settlements was affirmed in 2004 by the Alberta Court of Appeal in ATCO Electric Lid. v. Alberta (Energy and Utilities Board). ${ }^{37}$ While the decision dealt with regulation under the Electric Utilities $A c{ }^{38}$ the Negotiated Settlement Guidelines were also under consideration. The Court held that "the negotiated settlement process permits private sector settlement of disputes by regulated utilities; but subject to compliance with the public interest" 39 and affirmed the jurisdiction of the AEUB to consider the public interest in approving or dismissing negotiated settlements.

\section{B. Contractual Carriage}

Pipeline shippers may also find themselves in a situation where they have privately contracted for capacity, and find the regulator invoking discretion over the pipeline.

The settlement rules and guidelines above make it clear that the Boards wish to retain their jurisdiction over the parties even where they are negotiating among themselves. This is justified because of the Boards' jurisdiction to protect the public interest. In negotiations between private parties, those parties generally try to maximize their own interests. Larger public interest concerns are generally not considered.

Furthermore, private contracts may not be enforced when doing so would be counter to public policy. The general principle is that contracts that are contrary to statute are unenforceable. ${ }^{\text {to }}$ The reason is that it would be improper for the courts to enforce a contract that the legislature has said is not permissible. As discussed above, the NEB has specifically stated that its statutory powers are not constrained by contracts between individual parties." The AEUB has made a similar finding. ${ }^{42}$ Therefore, private parties may find that portions of their contracts, if not the entire contract, may be set aside when a regulatory board obtains jurisdiction over the pipeline in question. However, to the extent that the contracts do not contradict the relevant statutory provisions, it seems more likely that the regulatory boards will not intervene except in cases where the regulator believes that the public interest is not being served. 


\section{Common Carrier Obligations Revisited}

\section{A. \\ OIL vs. GaS}

Until about 20 years ago, the common thinking in regulatory circles was that oil pipelines and natural gas pipelines were fundamentally different from a regulatory perspective. Oil pipelines were, and are, considered to be common carriers. Natural gas pipelines, on the other hand, were considered to be contract carriers and so natural gas pipeline operations would provide service in accordance with the terms and conditions of contracts. Of significance is that whereas an oil pipeline, consistent with common carrier concepts, would allocate space in the event that nominations exceeded capacity, gas pipelines, for those with firm service contracts, would not allocate space.

\section{B. FEderal vs. Alberta}

The provisions of the $N E B \mathrm{ACr}^{3}$ provide for the oil versus gas distinction at the federal level. In Alberta, gas and oil lines are treated in the same fashion. Assuming that a particular line does not meet the definition of a public utility, absent further order of the AEUB, s. 48 of the $O G C A^{44}$ applies to both.

As noted above, both the NEB and AEUB have made provision for, and indeed encourage, settlement of disputes, tolls, terms and conditions of service, etc., by arrangement between the parties. Both have indicated strong support for market-based, as opposed to regulatory, solutions.

In the Peace Pipe Line case ${ }^{45}$ discussed eariler, the AEUB was dealing with an application to establish rates under what is now s. 110 of the $P U B A c r^{\text {th }}$ in circumstances where no application had been made to declare the pipeline a common carrier under $\mathbf{s}$. 50 of the $O G C A$, and where the parties had entered into contracts setting rates for pipeline service (the application had been made by a party which had not entered into a contract with the pipeline). The AEUB indicated that s. 110 of the PUB Act gives the AEUB jurisdiction to fix rates, tolls, and charges and that this provision was not limited to pipelines which had been declared to be common carriers. ${ }^{47}$

The AEUB extensively reviewed Alberta case law dealing with the power of the AEUB to override existing contractual provisions when fixing tolls and charges, and concluded, based on that review, that it had jurisdiction under s. 110 of the PUB Act to fix just and reasonable rates and tolls even if it could be said that in doing so, it would override the provisions of existing contracts. Having established its jurisdiction, the AEUB then went on to say that: 
Price or tariff regulation is generally required where a service or services are provided on a monopoly basis. It is widely recognized and accepted that a purpose of price regulation is to provide a surrogate for the competition that is absent in the monopoly situation. In this case, the Peace Pipeline System is not regulated as to tariffs and has not been during its some 30 years of existence... The Board is not convinced that unique circumstances exist in this case which would justify initiation of setting tolls for services on Peace's system or part thereof.

Il seems neither just nor reasonable that a certain owner, or owners of oil lines whose services are subject to significant and active competition should have rates and tolls set by a regulatory board when its competitors do not.

It dows not appear reasonable for the Board to implement toll fixing for services on Peace in view of the competitive climate in which such service is provided in Alberta. ${ }^{48}$

The Board continued:

The Board concludes further that the applicants, who also carry on business in the same competitive indusiry. have the same opportunities and business claallenges as do other shippers in Alberta who conduct their busincss without Board-approved tarifls.

The Board considers that the applicant's dispute with respect to toll-selting methodology can be resolved by them as would such other dispules between parties in a competitive business environment. ${ }^{49}$

One is left to speculate as to the circumstances in which the AEUB would intervene (having determined that it has the jurisdiction to do so). Clearly, a compelling public interest case, which could include criteria similar to that considered by the AEUB on common carrier access orders - duplication of facilities, fairness, conservation of resources, and so on must be made out.

Consistent with its embrace of market solutions, the NEB essentially accepted the negotiated position of the main players as to toll and tariff matters (in effect, the whole deal) in its decisions in Alliance Pipeline $e^{50}$ and Express Pipelines. ${ }^{51}$ These examples represent the "in-between" case, where the terms were negotiated by the pipeline and its shippers, and approval was granted by the NEB after public hearing (and over the objections of others).

\section{MYTHS EXPLODED (ERODED?)}

Subject to the comments above regarding the NEB's settlement guidelines and its salute to market-based negotiated solutions, the reality is that as a matter of law parties may not contract out of regulation by the NEB. Thus, for any facility under the NEB Act, ${ }^{52}$ the NEB has jurisdiction over tolls and charges, as well as terms and conditions of service, including

5. NEB, Alliance Pipeline Ital on Bchalf of the Alliance Pipeline Limited Parmership. Facilities and Tolls \& Tariffs, Reasons for Decision GH-3-97 (November 1998) [Alliance Pipeline].

SI Supra note 15 .

$\because \quad$ Supra note 3. 
access (and, as has been demonstrated, access is itself subject to a specific provision of the ACt-s. 71 ).

In Alberta, however, unless a particular facility meets the definition of a "public utility" as set out in the PUB Act (which includes a facility for which a common carrier order has been made), parties are free to operate outside the purview of the AEUB. Most oil sands pipelines operate in this way, as do the majority of producer-owned llowlines. However. as noted above, the AEUB has explicit powers to designate pipelines as common carriers (and similar powers with respect to processing plants) and the AEUB is not reluctant to exercise its jurisdiction where relevant criteria are met, particularly with regard to environmental footprint, duplication of facilities, and drainage. As has been seen from an examination of the Peace Pipe Line case, ${ }^{54}$ the AEUB will, in the appropriate case, exercise rates jurisdiction over an otherwise unregulated pipeline notwithstanding that no application was made for common carrier status (and thus public utility status).

The last development worth noting relates to long-term contracts. As stated earlier, the historical development of oil and gas pipelines was somewhat different. One of the aspects of this difference relates to the status of contracts for service on the linc. Customers on gas pipelines have firm service agreements, entitling them to unallocated (except in the case of emergency) service for a fixed term, with rights to renew. Customers on oil pipelines such as Enbridge and Terasen (TransMountain) typically have a contract for service (which may in fact not be anything different than nominations and payment pursuant to the tariff) for one month, and deliveries are subject to allocation absent a priority access or priority designation order by the NEB.

This should not be confused, however, with whether or not long-term contracts are needed to underpin facilities. In the not too distant past, TransCanada's average contract term was in excess of ten years and over the past eight years or so it has fallen to low single digits, and renewals typically occur on a one-year basis, which themselves have one year (or longer, if the shipper desires) renewal rights.

What can now be observed is that any request for new facilities for gas or oil pipelines requiring significant capital investment will likely require long-term commitments by shippers. This is certainly true for greenfield projects, but also applies to expansions of existing systems, oil or gas.

This is not without its ironies - for example, there are no long-term contracts currently on Terasen (TransMountain) but, anecdotally, it is understood that in discussions related to expansion of that facility, the parties are discussing long-term commitments from shippers, both new and existing, on all facilities, new and existing.

Further, in the recent Trans-Northern ${ }^{55}$ case discussed earlier, the capital investment was supported, in part, by long-term commitments from both Ultramar and Petro Canada. 
The apparent need for such long-term commitments by shippers, and its implications, are discussed below.

\section{Producers as Pipeline OWners/Developers}

While there are cases where producers have been or are the developers and/or owners of pipeline facilities (for example, Alberta gas flowlines and certain oil pipeline facilities), generally the historical model is that producers produce and sell oil or gas, and other investors - pipelinc operators - invest in pipeline facilities and operate them. This model has, over time, produced its own set of tensions between pipeline operators and producers which continue to date.

With regard to major projects in the recent past, and currently moving forward, there is an emergence of producers taking the lead in an ownership position in pipelines. This started with the Alliance Pipeline and, although the producers ultimately sold their interest to traditional pipeline companies, it was indicative of a desire by the producer community to meet their own needs where they felt that the traditional pipeline community was not doing so.

Currently, the Mackenzie Gas Project has been developed by and is owned by producer interests and such owners are the anchor shippers, so to speak, in the pipeline proposal. At least one of the possible solutions to the transport of Alaska gas involves the producers of that gas.

Several oil sands operators are eyeing ownership of pipeline facilities needed to ship incremental production. Inherently, this is neither good nor bad. However, a whole new series of issues is introduced concerning competitive considerations, tolls, access, and other terms and conditions of service, particularly from the perspective of a third party (that is, non-owner) shipper. In considering some of the major issues touched on below, the nature of pipeline ownership is going to have an impact on their resolution and must be taken into account.

\section{E. OIL Pipelines as Common Cairiters}

The legislative framework in broad regulatory principles concerning oil pipelines as common carriers have been reviewed above, as have the modifications to an oil pipeline's common carrier duties made by the NEB. As a result of those modifications, one must conclude that oil pipelines are conditional common carriers and, in many respects, this is consistent with the opening words of s. 71 (1) of the $N E B A c t,{ }^{56}$ which makes the obligation subject to exemptions and conditions as ordered by the NEB.

In most of the cases discussed above, where priority access was granted to one or more shippers, those shippers had made financial or long-term commitments, or both, to the pipeline, and this factor was critical to the NEB's determination. What is significant is that in granting priority access, the NEB was not granting an exemption to the common carrier 
obligations, but rather determined that priority access, particularly where supported by longterm commitments, and where resulting from an open season or similar process available to all potential shippers, was consistent with the common carrier obligation.

In the Trans-Northern case, the NEB said as follows:

The Board is of the view that establishing the appropriate level of capacily which will be available for spot shippers is a matter ol judgment and involves a balancing of interests. In this instance, the Board is saltislied that Trans-Northern is meeting its common carrier obligations under the NFB $A$ ct. and that an order exempting the Applicant from the provisions of section 71 is not necessary in the circumstances.

This decision is based primarily on two considerations.

Second, as the Board lound for the reasons given previously, a satisfactory open season was conducled.

Further, the Board had regard to the fact that Trans-Northem is a refined products pipeline and, while pipelines are recognized by many as being the preferred means of moving product, given their sale and economical nature, there are viable altematives available.

The Board does not aceept Suncor's recommendation that Petro Canada and Ultramar [ncw priority aceess shippers] not be allowed to share in the available unsubscribed capacity unless third parties do not completely fill the pipeline. In the Beard's view, such a suggestion is not in keeping with the common carrier principle and would amount to giving priority access to spot shippers. 57

Chevron Canada Resources has recently made an application to the NEB for priority destination status for its refinery in Burnaby, B.C., off the Terasen (TransMountain) system. Of significance, unlike most earlier $\mathrm{s} .71$ proceedings, Chevron's request is not supported by a long-term commitment to use the pipeline. It is anticipated that the NEB's ultimate disposition of this application will add to the growing body of regulatory jurisprudence shaping an oil pipeline's traditional common carrier obligations.

These issues are of particular significance in light of the considerable growth in oil pipeline capacity needed as a result of substantial increases in oil sands production. Parties need to know what the ground rules will be concerning access to those new facilities and whether the traditional common carrier approach will apply or whether, in fact, the effect of what has occurred over the last ten years or so is the creation of a hybrid pipeline taking aspects of both traditional oil and gas pipelines.

These issues are even more critical to the second and third generation of shippers, and the issues are not restricted to federally regulated oil pipelines. As noted earlier, the existing pipelines from the oil sands to Edmonton and areas are private contracts between pipeline operators and shippers. No one has yet moved forward with a common carrier application 
with respect to them. However, given the nature of the substantial investments required related to incremental oil sands production, shippers will likely require fixed commitments guaranteeing that all, or substantially all, of their product can be moved to market.

The relief available to the next generation of producers has been outlined above; both federal and Alberta legislation allow for applications either to get on the line, or to have additional facilities constructed (in the case of s. 7l(3) of the $N E B A c t$ ).

\section{Contracit Carriage Arrangements}

\section{A. The. Oll Sands Case.}

As has been previously noted, oil sands product (either upgraded synthetic crude or diluent blends) move by pipeline from the Fort McMurray area to Edmonton and other like destinations. Those arrangements are subject to Alberta law but operate beyond the purview of the AEUB. They were created out of intense negotiations between pipeline operators and oil sands producers.

The contracts are lengthy, complex documents, and resemble typical regulated pipeline tariffs.

These documents are also confidential, as are the results of various arbitration or other dispute resolution proceedings between the parties to those contracts.

A typical contract between an oil sand shipper or shippers, and pipeline operator, in effect mimics the regulatory framework applicable to NEB or AEUB regulated pipelines. The contract is the "constitution" referred to at the beginning of this article.

What makes all of these contracts different than a pipeline tariff is that the parties have typically expended significant effort to detail how charges will be determined (in regulated terms, we would call them tolls). For a regulated pipeline, one would have to examine a series of regulatory decisions to obtain equivalent information.

If one wandered through a typical oil sands pipeline contract, one would find provisions dealing with the commitments of the parties, issues surrounding decision making and control (which might involve a shipper's committee), detailed provisions dealing with the operation of the pipeline, construction and specifications, determination and payment of charges, accounting procedures, audit and inspection rights, arbitration rights, future development and capital additions, dispute resolution, force majeure, liability and indemnity, and a whole series of general contractual issues. As noted, they are exceedingly complex, particularly the provisions relating to the determination of charges and, in particular, the calculation of what amounts to the pipeline's profit.

In a general sense, we will review the issues confronting those now negotiating new oil sands (and other) contracts below. 


\section{B. THE MAJOR ISSUES}

Pipelines typically are viewed as less risky than a host of other investments in the oil and gas sector, and thus are typically highly leveraged. As a consequence, there are three parties - not two - at the negotiating table. While the interests of financiers have always been important, if not critical, to pipeline development, ${ }^{5 x}$ and the interests of third party lenders have often informed, if not driven, the resulting business provisions, arguably this has never been more of a factor than it is today.

The emerging issue relates to the relative balance sheet strength of pipeline proponents and their prospective shippers (the issue is differently cast for the producer/owner proposals where the financial community is looking directly at the proponents in their producer capacity). In turn, coupled with the ever increasing cost of pipeline projects and the resource development underpinning them. this has led to a resurgent demand for long-term commitments from shippers to support the projects. Anecdotally. it appears that certain projects, especially those deriving product from nascent basins, will not move forward without long-term contractual commitments.

Thus, for oil and gas practitioners, regardless of which of the "three" sides of the deal they are on, the following issues will arise for resolution at the boardroom table and/or before the regulator.

\section{NATURE OI: TIE COMMITMENT}

In light of the interests of third party lenders described above, and given the uncertain. expensive and complex nature, to varying degrees, of the underlying resource developments fuelling the current slate of pipeline proposals (Mackenzie Valley, Alaska, Oil Sands), it is hardly surprising that the nature of a shipper's commitment to a pipeline project is front and centre in negotiations. In some respects pipeline operators (driven at least, in part, by their prospective equity investors and lenders) are looking to the scope and strength of shipper commitments, and shipper balance sheets.

Thus, a host of issues touching upon a prospective shipper's financial commitment must be resolved, including the backstopping of construction costs, ship or pay covenants, reserves dedication, the fundamental nature of the liability (joint vs. several), and so-called force majeure provisos. In many respects, this whole series of issues relates to risk and who bears it.

In this context, force majeure provisions should be seen as the parties' agreement to what will happen if a series of events beyond the control of either party were to occur. In effect. a force majewre clause is an express term governing circumstances which may, or may not, otherwise constitute frustration of contract. 
It may be observed anecdotally that force majeure provisions are all too liberally cut and pasted from prior transactions, rather than tailored to the particular pipeline project, and the nature of the other risk-related provisions. Force majeure provisions are contained in all pipeline tariffs and in all of the contract carriage arrangements. Many have not been reviewed or revised for a long period of time.

\section{CONTROL. ISSUES}

Another hot set of issues concern what may be thought of as control-related. In a conventional, traditional pipeline setting, shippers have a relatively modest level of influence over a series of decisions. This has changed over the past ten to 15 years with the institution of shipper task forces and the like. To varying degrees, the oil sands private pipeline agreements contain provisions dealing with product movement (nominations and allocation), shippers' committees, and the scope of their authority to influence or change operating decisions, capital additions, accounting obligations, audit rights, and arbitration of both toll and non-toll related disputes. The greater the shipper's commitment to the project, both in terms of percentage of product and nature of the commitment (see above), the more likely a shipper will seck significant control-related responsibilities. Indeed, it may be argued that, balance sheet issues aside, a desire for greater control where a shipper is the anchor or sole shipper has led to a shipper's (producer's) desire to own and operate the pipeline.

\section{TOLLS AND RESOLUTION OF DISPUTES}

In a regulated context, a pipeline generator's capital decisions are subject to a prudency test, and all of its expenses must be proven to be reasonable, and taken together, its capital related charges (interest, return on equity, income taxes, property taxes, and depreciation) and operating expenses constitute its toll. Under traditional regulatory models, the tolls must be just and reasonable.

While that term is a bit like an ("I know it when I see it"), guidelines of sorts have been developed over the years, associated with the reasonableness of the underlying expenses and cost-causation relative to the service provided.

Most of the private pipeline agreements contain extensive provisions detailing how pipeline charges are to be determined, and provide for various approaches for dealing with charge-related disputes. Some incorporate directly, or by reference, just and reasonable tollmaking principles. Others merely provide an auditarbitration right relative to compliance with the terms of the agreement. In theory, these provisions should fit with the control related issues. For example, if a shipper participated in decisions related to certain expenses or capital additions, how can it complain of the toll consequences?

The point is this: a pipeline agreement (or draft tariff if negotiations precede a filing with the NEB in the case of a federal pipeline) should reflect the project and its risks and be internally consistent. For example, dispute resolution should reflect control; equity return should relate to risk and financial commitment. 


\section{Conclusion}

This article has reviewed the legislative framework governing access to oil and gas pipelines, and has indirectly dealt with the broader legislated jurisdiction of federal and Alberta regulators over pipelines in their jurisdictions.

In the concluding sections, the major issues that must be addressed in a pipeline tariff or agreement have been briefly described. It is clear that either constitution can work. Arguments can certainly be made (see for example the pre-filed evidence of Jeffery Church on behalf of the Mackenzie Explorers Group in the Mackenzie Gas Project case ${ }^{59}$ ) that, particularly where the future is characterized by uncertainty, complexity and high cost (and where pipeline tariffs or agreements must necessarily reflect those). regulation is superior to private contracts for reasons of cost efficiency, economy of scale, and specialization.

On the other hand, regulation has limitations that have been well documented and editorialized elsewhere.

Fundamentally, the public interest trumps all. The public interest is explicitly included in various federal and Alberta regulatory statutes. It also forms part of the decision-making process of regulators, even where not explicitly included as a criterion. Given the history of regulation going back several centuries, applicable to those whose affairs affect the public interest, and given regulation's ability to withstand the market-driven economic reforms of laissez-faire (thus regulation promises to go where the invisible hand of Adam Smith could not), it is hardly surprising that the public interest remains dominant. It will be viewed by regulators as being of particular importance where a broader public interest (for example, development of a new gas basin, exploitation and movement to market of the oil sands) is in play. In these circumstances, regulators will not hesitate to intervene. 